\title{
CONSTITUTIONAL IDENTITY IN THE ARGUMENTATION OF DECISIONS OF CONSTITUTIONAL COURTS
}

\author{
Oksana Shcherbanyuk, \\ Head of the Department of Procedural Law, \\ Yuriy Fedkovych Chernivtsi National University, \\ Doctor of Juridical Science, Associate Professor \\ https://orcid.org/0000-0002-1307-2535 \\ Scopus ID: \\ https://www.scopus.com/authid/detail.uri?authorId=57217827953\&eid=2-s2.0-85087613989 \\ Researcher ID: D-9287-2016 \\ oksanashcherbanyuk7@gmail.com; o.shcherbanyuk@chnu.edu.ua
}

\section{Summary}

The latest trend in modern European constitutionalism is the issue of constitutional identity. Constitutional courts, which are the embodiment not only of the protection of the Constitution, but also of the limitation of power, are influential subjects of assessing the country's international obligations and their implementation in national legislation. The purpose of the article is to analyze the constitutional identity in the argumentation of decisions of constitutional courts.

The research method is a comparative legal analysis of the practice of constitutional review bodies in order to assess the expression of the concept of respect for national identity, which has become a condition and principle of legal integration in the European region. In addition, empirical analysis of decisions of constitutional courts was used. Using the system-structural method, the doctrine of «constitutional boundaries» as a component of constitutional identity is analyzed.

It is justified that the concept of «identity" appeared and began to be actively used by European constitutional courts to justify decisions related to the processes of European integration and the expansion of the influence of supranational institutions of international organizations, including the European Union. It is proved that the decisions of constitutional courts should be based on national legal values, taking into account international practice and the principle of the supremacy of the Constitution. At the same time, national courts must take into account the country's international obligations when making decisions. In today's world, constitutional courts cooperate with the courts of international organizations, which form a common case law in the member states, in particular on the interpretation of human rights. This is manifested in the citation by constitutional courts in their acts of decisions of supranational judicial bodies. It should also be noted that the constitutional court may be guided by the positions of international courts in forming its legal position, but according to the doctrine of judicial discretion, the national court is free to assess the circumstances of the case and it is best acquainted with national features and specifics of national law.

The analysis of the decisions of the bodies of constitutional proceedings, which used the concept of constitutional identity, gave grounds to claim that the courts in their practice in their interpretation appealed to different arguments depending on the specifics of the case. For example, in formulating the doctrine of constitutional boundaries, the Constitutional Court of Italy, in substantiating its decision, used at the same time an argument by analogy, an argument of agreement, an argument of general principles. The Federal Constitutional Court of Germany in its decision in the case of the Maastricht Treaty resorted to naturalistic and systemic arguments. 
It is concluded that constitutional identity is a system of interpretive arguments used by constitutional courts to substantiate decisions that verify compliance with the national specifics of constitutional norms. Of course, this applies to the categories of so-called «difficult cases», for the argumentation of which requires a system of strong arguments.

Key words: constitutional proceedings; constitutional argumentation; national identity; interpretive argument; constitutionalism.

\section{Introduction.}

Constitutional identity is a relatively new concept in the theory of constitutional law, which appeared in the motivating part of the decisions of constitutional courts in the second half of the twentieth century in connection with the cases related to the process of European integration.

Over the last few years, national constitutional identity has become a new trend in European constitutionalism. The concept of national identity is welcomed by some authors, others demonize its implications for the EU, and others discuss important decisions of the constitutional courts. In modern conditions, scholars and judges have made the concept of constitutional identity so fashionable and yet so ambiguous that an in-depth analysis of constitutional identity is necessary.

The European Constitutional Courts have begun to use this concept as a legal counterargument against the influence of the European Court on the national legal systems of the Member States.

At the theoretical level, the use of this new concept has provoked much criticism from legal scholars because, in their view, its non-legal and non-scientific nature. At the same time, there were many supporters of this concept, who are representatives of civilizational and socio-cultural approaches to law. One way or another, this concept has attracted the attention of constitutional scholars who have not yet developed a common understanding of the concept. Some of them suggest defining constitutional identity as a method of legal argumentation.

The doctrine of constitutional identity was formed on the basis of judicial practice, including national constitutional courts (which implement the function of constitutional interpretation). At the same time, it was often seen as a kind of reflection of the concept of respect for national identity, which became a condition and principle of legal integration in the European region.

\section{Constitutional identity as a constitutional argument in the decisions of the Federal Constitutional Court of Germany}

"Constitutional identity" is little studied in legal doctrine (Rosenfeld, 1994; Jacobsohn, 2006, p. 361; Arnaiz \& Llivina, 2013) And constitutional jurisprudence. As noted in the legal literature, from a doctrinal point of view, the concept of «identity» has been mainly studied in social research (Śledzińska-Simon, 2015, p. 124-155) and only recently began to attract the attention of legal scholars studying international law. and constitutional scholars. The reason for the increased attention to this topic in legal science is that the concept of «identity» has emerged and is actively used by European constitutional courts to justify decisions related to European integration and expanding the influence of supranational institutions of international organizations, including the European Union. However, it is the consistent ratification of international treaties concerning the establishment and empowerment of the institutions of the European Union, in particular the Maastricht and Lisbon Treaties, that has led to the emergence of modern research on constitutional identity (Martí, 2013, p. 17-36; Kucherenko, Klochko, 2019, p. 99-124).

The judgment of the Federal Constitutional Court of Germany in the Gorgul case of 14 October 2004 opened a new stage in the relations between the European Court of Human Rights and national constitutional justice bodies, setting a precedent for "principled resistance» to the legal positions of the European Court of $\mathrm{Hu}$ man Rights. Of particular interest is the argument used by the German Federal Constitutional Court to justify non-compliance with the judg- 
ment of the European Court of Human Rights, in particular the interpretation of acts of the European Court of Human Rights as "ultra vires» (illegal acts beyond jurisdiction). To begin with, it is necessary to consider the constitutional and legal significance of an international legal treaty in the German legal system. Gorgül v. Germany is also interesting in that it has identified this fundamental issue for the German legal order. Of course, the Federal Constitutional Court of Germany could avoid considering it only on the basis of national law. However, the body of constitutional proceedings directly raised the question of the status of the legal positions of the European Court of Human Rights.

Having examined the provisions of Art. 23, 24, 25 and Art. 59 of the Basic Law of Germany, the Federal Constitutional Court came to the following conclusions:

- firstly, despite the commitment and openness of the German legal order to international law, judgments based on the law of the European Convention for the Protection of Human Rights and Fundamental Freedoms are an order of magnitude lower than German constitutional law;

- secondly, «the legal force of judgments of the European Court of Human Rights extends in accordance with international legal principles, first of all, to the member states themselves as such» and cannot oblige public authorities to take certain actions, as this would be interference. In the domestic sphere of regulation. The Federal Constitutional Court of Germany noted that only the constitutional review body has such powers (according to $\S 31$ para. 1 of the FCC Act);

- thirdly, under the obligations arising from Art. 52 of the European Convention for the Protection of Human Rights and Fundamental Freedoms («effective enforcement of any provision»), the Federal Constitutional Court of Germany understands above all the obligation to take these provisions into account, but this does not mean that they must be followed in all cases. National courts cannot mechanically comply with the position of the European Court of Human Rights, especially in cases where there are «various legal relationships related to the exercise of constitutional rights, for example, in private law»;

- fourthly, even if a judgment of the European Court of Human Rights finds that a national court's decision is contrary to the Convention, it does not «affect the legal force of that decision" because it is not provided for in either the Convention or the Constitution (BVerfG, Order of the Second Senate of 14 October $2004-2$ BvR 1481/04).

In this case, the Federal Constitutional Court of Germany separated its jurisdiction from that of the European Court of Human Rights. It was determined that the European Convention for the Protection of Human Rights and Fundamental Freedoms has the status of a federal law, i.e. the Federal Constitutional Court of Germany has not made the provisions of the European Convention and the case law of the European Court of Human Rights constitutional. However, he noted that the Convention is important in the case law of the Federal Constitutional Court of Germany and in the implementation of international principles in the German legal system.

Thus, the Federal Constitutional Court of Germany has stated that national courts are not obliged to review their decisions on the basis of the rulings of the European Court of Human Rights. However, the Federal Constitutional Court of Germany has made an important caveat - in some cases, German courts may review the case and take into account the position of the European Court of Human Rights, but this is not a general rule of interaction between these jurisdictions, as there must be real procedural possibilities.

Such a possibility is provided only in the Criminal Procedure Code of Germany in paragraph 6 of $\S 359$ of the CPC «Restoration in favor of the convict», i.e. review is possible only in criminal cases. The German Federal Constitutional Court also ruled that civil proceedings had a different specificity, and that the position of the European Court of Human Rights in this area could not reflect a real balance of rights and interests «alongside the applicant and the Court. Only the State Party concerned; the possibility of third parties participating in the complaint proceedings (Article $36 \S 2$ of the ECHR) is not the institutional equivalent of the rights and obligations of a party to the proceedings or other persons admitted to the national proceedings» (BVerfG, Order of the Second Senate of 14 October 2004 - 2 BvR 1481/04).

Thus, the Federal Constitutional Court of Germany has established a clear framework 
for cooperation between the two jurisdictions, based on the recognition of the limited legal impact of the Convention on the national legal system. The Federal Constitutional Court has ruled that «the law of the Convention does not take precedence over federal law, especially if it has not previously been the subject of a judgment of the European Court of Human Rights». Elements of the dualistic approach can be traced in this position.

The Federal Constitutional Court sees the legal impact of the rulings of the European Court of Human Rights in the use of these acts as "ancillary to the interpretation" of German constitutional rights and freedoms. Cases of misapplication or non-compliance with international legal obligations by German courts are the exclusive jurisdiction of the Federal Constitutional Court of Germany. This competence is exercised by the Federal Constitutional Court, resolving disputes taking into account the position of the European Court of Human Rights.

In this regard, it is pertinent to recall the history of relations between the Federal Constitutional Court of Germany and another supranational body, the European Court of Justice, which also claimed the role of «supreme arbiter» in an attempt to invade constitutional regulation (ECJ, Case 11-70). The Federal Constitutional Court responded with a ruling by Solange I, in which (as in the Gorgul case) it refused to recognize the primacy of supranational regulation (ECJ, Case 11-70).

The model of judicial cooperation proposed in the Solange I case provided that a supranational body has the exclusive right to interpret at its level, and a national court has the competence to determine the limits of integration of supranational norms (the doctrine of constitutional limits).

A similar position is taken by the Italian Constitutional Court, declaring its right to constitutional review of those acts of the European Union in the adoption of which the Union acted within its competence (ultra vires) (Sentenza 183/1973. Deposito del 27/12/1973). Thus, there is a certain continuity of the positions of the Federal Constitutional Court of Germany on the protection of its constitutional identity (Sentenza 183/1973. Deposito del 27/12/1973). A similar approach was used by the FCC in the case of Görgülü v. Germany of 14 October 2014. According to this judgment of the Federal Constitutional Court of Germany, «The Basic Law aims to integrate Germany into the legal community of peaceful free states, but it does not provide for the renunciation of sovereignty enshrined, above all, in the German Constitution. Thus, this does not violate the aim of adhering to international law if the legislator, as an exception, does not respect the law of international treaties, provided that this is the only possible way to avoid violating fundamental constitutional principles» (BVerfG, Order of the Second Senate of 14 October 2004 BvR 1481/04).

\section{The doctrine of «constitutional boundaries» and constitutional identity.}

In the legal positions analyzed above, the Federal Constitutional Court of Germany develops and formalizes the doctrine of constitutional boundaries and allocates a special area of legal regulation that has "immunity" from decisions of international justice bodies, which the Court calls the "constitutional core».

In this regard, the doctrine of constitutional boundaries and the related concept of «constitutional identity" need to be examined in more detail. The concept of counter-boundaries or constitutional boundaries originated in Italian legal doctrine, and its author is Paolo Barile. According to his approach, there is limited legal influence of European Union and UN law in the national legal system, and the degree of integration of supranational norms is based on their compliance with the general principles of the constitutional order of the country. These principles are recognized as a barrier (counter-limit), a kind of limit for the action of community norms. Since its inception, this doctrine has received formal support in the relevant decisions of the constitutional courts of Italy and Germany. The Italian Constitutional Court's judgment of 27 December 1973 № 183/73, the Frontini case and the German Federal Constitutional Court's judgment of 25 May 1974 (Solange I) set out the main provisions of this doctrine.

The national constitutional justice authorities reach similar conclusions in these decisions: despite the recognition of the rule of law of the European Union, if these norms contradict the 
«basic principles of the constitutional order» or «fundamental constitutional rights» they cannot be applied in domestic law.

It should be noted that the doctrine of constitutional boundaries has been used in assessing the constitutionality of not only international obligations arising from European Union law. The most significant here is the Judgment of the Italian Constitutional Court of 22 October 2014 № 238, in which the doctrine of constitutional boundaries applies to obligations arising from the UN Charter (Article 94 of the International Court of Justice) (Sentenza 238/2014). Deposit of 22/10/2014). The Court of Florence considered the constitutionality of the first paragraph of Article 10 of the Italian Constitution, in so far as it obliges a national judge to abide by a ruling of the UN International Court of Justice when it established an Italian judge's obligation to deny him jurisdiction. Against humanity committed by the Third Reich in Italy. This is a conflict between the Italian Constitutional Court and the UN International Court of Justice. Italy lost the case to Germany in a UN court and undertook to comply with a number of regulations to improve its legislation. The Constitutional Court of Italy, assessing the decision, pointed out that the implementation of the norm of international law is possible only if it complies with the Constitution of Italy and constitutional human rights and freedoms. Exercising its competence to assess the norms of international law on their constitutionality, the Constitutional Court of Italy did not allow the implementation of the decision of the International Court of Justice in Italy, citing the constitutional barrier and protection of human rights and freedoms in its territory. Thus, the prototype of the concept of constitutional identity in Italian constitutional jurisprudence was the doctrine of constitutional boundaries, which the Italian Constitutional Court defined as the basis of constitutional principles and fundamental rights guaranteed by the Constitution.

The broad wording of the concept of «national identity" in the Lisbon Treaty suggests that the new norm's focus on the functional features of the state shifts the emphasis from national to constitutional identity, as a result of which European constitutional courts have developed their own concepts of constitutional state identity. The practice of cooperation between the Euro- pean Court of Human Rights and the Constitutional Court of Bosnia and Herzegovina is quite interesting. The peculiarity of their relationship is that the European Court of Human Rights, as a court of an international organization and a supranational body, participates in the formation of the judiciary of the Constitutional Court of Bosnia and Herzegovina, and the President of the European Court of Human Rights has the right to appoint 3 judges.

\section{Relationship between constitutional courts and courts of international organizations: cooperation or autonomy?}

The emergence of a supranational legal order causes a change in the relationship between the constitutional courts and the courts of international organizations. What can be their forms of interaction? Cooperation, confrontation, autonomy? National constitutional courts do not procedurally interact with each other, have different legal principles of formation and organization, competence. However, their tasks and functions for the protection of the constitution are common. In today's world, constitutional courts cooperate with the courts of international organizations, which form a common case law in the member states, in particular on the interpretation of human rights. This is manifested in the citation by constitutional courts in their acts of decisions of supranational judicial bodies. It should also be noted that the constitutional court may be guided by the positions of international courts in forming its legal position, but according to the doctrine of judicial discretion, the national court is free to assess the circumstances of the case and it is best acquainted with national features and specifics of national law.

In our opinion, the decision of the constitutional courts should be based on national legal values, taking into account international practice and the principle of the supremacy of the Constitution. At the same time, national courts must take into account the country's international obligations when making decisions.

The issue of constitutional identity in American doctrine and constitutional law enforcement practice should be considered through the prism of problems of interpretation and use of constitutional borrowings, which emphasizes the fact 
that the concept of constitutional identity is not least related to constitutional interpretation.

According to M. Savenko: «References to the provisions of the Constitution or international acts, decisions of the European Court of Human Rights, and unsubstantiated statements in one's own decisions cannot be regarded as an argument. A simple set of such references or extraction of certain provisions of a court's reasoning does not meet the requirements for the content of the motivating part of the decision, they do not create a belief in the validity of the arguments of the Court's position, and therefore unmotivated decision cannot be considered legitimate. It is inadmissible to use in the argumentation of such a technical and legal technique as legal fiction, as well as shuffling, manipulation of the statements of the European Court of Human Rights and its own decisions, arguments in order to create the illusion of persuasiveness of the position of the Court.

Such actions have signs of argumentative fraud, and with such "arguments" the decision of the Court cannot be considered fair with the corresponding consequences for the judges who voted for it» (Savenko, 2012, p.14).

Also in the context of our study, it should be noted that "constitutional identity" is a set of «interpretive arguments». According to A. Reiner, "constitutional identity is a conceptual tool for protection against supranationalization of legal orders, protection of material and functional existence of the state, expressed in the main political decisions and basic elements of its legal culture, which are the value basis of the Constitution» (Rainer, 2019).

\section{Conclusions.}

Without entering into a discussion on the fairness of the use of the concept of constitutional identity, it is possible to raise the question of the correctness of the characterization of this phenomenon as an independent legal argument.

The analysis of the decisions of the bodies of constitutional proceedings, in which this concept was used, gives grounds to assert that the courts in their practice in their interpretation appealed to different arguments depending on the specifics of a particular case.

For example, in formulating the doctrine of constitutional boundaries, the Constitutional
Court of Italy, in substantiating its decision, used at the same time an argument by analogy, an argument of agreement, an argument of general principles. The Federal Constitutional Court of Germany in its decision in the case of the Maastricht Treaty resorted to naturalistic and systemic arguments.

That is, constitutional identity is a system of interpretive arguments used by constitutional courts to substantiate decisions that verify compliance with the national specifics of constitutional norms. Of course, this applies to the categories of so-called «difficult cases», for the argumentation of which requires a system of strong arguments.

\section{References}

1. Arnaiz, Alejandro Saiz \& Llivina, Carina Alcoberro. (2013) National Constitutional Identity and European Integration. Cambridge [etc.]: Intersentia, ] cop. 2013. 326 p. Available from: https://dialnet.unirioja.es/servlet/libro?codigo=713790 [in English].

2. Judgment of the Court of 17 December 1970. Internationale Handelsgesellschaft $\mathrm{mbH} \vee$ Einfuhr- und Vorratsstelle für Getreide und Futtermittel. Reference for a preliminary ruling: Verwaltungsgericht Frankfurt am Main-Germany. Case 11-70. Available from: https:// eur-lex.europa.eu/legal-content/EN/TXT/?uri=CELEX\%3A61970CJ0011 [in English]

3. Faraguna, Pietro. (2016). Taking Constitutional Identities Away from the Courts. Brooklyn Journal of International Law. Vol. 41:2. 490-578. Available from: https:// core.ac.uk/download/pdf/54549653.pdf [in English].

4. Jacobsohn, G. (2006). Constitutional Identity. The Review of Politics, 68(3), 361-397.DOI: 10.1017/ S0034670506000192 [in English].

5. Kucherenko, P., Klochko, E. (2019) The Concept of Constitutional Identity as a Legal Argument in Constitutional Judicial Practice. Russian Law Journal. 2019;7(4):99-124. DOI: 10.17589/2309-8678-2019-74-99-124 [in English].

6. Marti, Jose Luis. (2013). Two Different Ideas of Constitutional Identity: Identity of the Constitution v. Identity of the People. In National Constitutional Identity and European Integration, edited by Alejandro Saiz Arnaiz and Carina Alcoberro Llivina, 17-36. Antwerp: Intersentia. [in English].

7. Rainer, Arnold. (2014). Constitutional Identity in European Constitutionalism. International conference "The role of constitutional justice in protecting the values of the rule of law» (8-9 September 2014, Chisinau). Available from: http://www.constcourt.md/public/files/file/ 
conferinta_20ani/programul_conferintei/rainer_Arnold.pdf. [in English].

8. Finn, J. (1996). Constitutionalism, Identity, Difference, and Legitimacy: Theoretical Perspectives. Edited by Michel Rosenfeld. Durham: Duke University Press, 1994. 434p. American Political Science Review, 90(1), 224225. doi:10.2307/2082866. [in English].

9. Savenko, M. D. (2012). Yurydychna arhumentatsiia $v$ konstytutsiinomu sudovomu protsesi: metodolohichnyi aspekt. NAUKOVI ZAPYSKY NaUKMA. Tom 129. Yurydychni nauky. 11-15. [in Ukrainian].

10. Śledzińska-Simon, Anna. (2015). Constitutional identity in 3D: A model of individual, relational, and collective self and its application in Poland. International Journal of Constitutional Law, Volume 13, Issue 1, January. 124-155, DOI: 10.1093/icon/mov007 [in English].
11. Sentenza la Corte Constituzionale Italian 183/1973. (1973) Deposito del 27/12/1973. Pubblicazione in «Gazz. Uff.» n. 2 del 2 gennaio 1974. Available from: https://www.cortecostituzionale.it/actionRicercaSemantica.do [in English].

12. BVerfGE 37, 2712 BvL 52/71 Solange I-Beschluß 29 May 1974. Available from: https://law.utexas.edu/ transnational/foreign-lawtranslations/german/case. php?id=588https://law.utexas.edu/transnational/ foreignlawtranslations/german/case.php?id=58 8 [in English].

13. BVerfG, Order of the Second Senate of 14 October 2004 - 2 BvR 1481/04-, paras. 1-72. Available from: https://www.bundesverfassungsgericht.de/SharedDocs/Entscheidungen/EN/2004/10/rs20041014_2bvr148104en.html [in English].

\section{КОНСТИТУЦІЙНА ІДЕНТИЧНІСТЬ В АРГУМЕНТАЦІЇ РІШЕНЬ КОНСТИТУЦІЙНИХ СУДІВ Оксана Щербанюк}

завідувачка кафедрою процесуального права,

Чернівецький національний університет імені Юрія Федьковича,

доктор юридичних наук, дочент

https://orcid.org/0000-0002-1307-2535

Scopus ID:

https://www.scopus.com/authid/detail.uri?authorld=57217827953\&eid=2-s2.0-85087613989

Researcher ID: D-9287-2016

oksanashcherbanyuk7@gmail.com; o.shcherbanyuk@chnu.edu.ua

\section{Анотація}

Сучасним напрямком сучасного європейського конституціоналізму є питання конституційної ідентичності. Конституційні суди, які є втіленням не лише захисту Конституції, але й обмеження влади, $\epsilon$ впливовими суб'єктами оцінки міжнародних зобов'язань країни та їх реалізації у національному законодавстві. Метою статті є аналіз конституційної ідентичності в аргументації рішень конституційних судів. Метод дослідження - порівняльно-правовий аналіз практики органів конституційного контролю з метою оцінки вираження концепції поваги національної ідентичності, яка стала умовою та принципом правової інтеграції в європейському регіоні. Крім того, використовувався емпіричний аналіз рішень конституційних судів. За допомогою системно-структурного методу проаналізована доктрина про «конституційні межі» як складова конституційної ідентичності.

Відзначається, що поняття «ідентичність» зявилось і стало активно використовуватися європейськими конституційними судами для обгрунтування рішень, повязаних із процесами європейської інтеграції та розширенням впливу наднаціональних інституцій міжнародних організацій, зокрема Європейського Союзу. Доведено, що рішення конституційних судів повинні базуватися на національних правових цінностях з урахуванням міжнародної практики та принципу верховенства Конституції. У той же час національні суди повинні враховувати міжнародні зобовязання країни при прийнятті рішень. У сучасному світі конституційні суди співпрацюють із судами міжнародних організацій, які формують загальну прецедентну практику в державах-членах, зокрема щодо тлумачення прав людини. Це виявляється у цитуванні конституційними судами своїх актів рішень наднаціональних судових органів. Слід також зазначити, що при формуванні своєї правовоі позиції конституційний суд може керуватися позиціями міжнародних судів, але згідно з доктриною судового 
розсуду національний суд може вільно оцінювати обставини справи, і його найкраще знати з національними особливостями та специфікою національного законодавства.

Аналіз рішень органів конституційного судочинства, які використовували поняття конституційної ідентичності, дав підставу стверджувати, що суди у своїй практиці в своїй інтерпретації апелювали до різних аргументів в залежності від особливостей справи. Наприклад, формулюючи доктрину конституційних кордонів, Конституційний Суд Італії, обгрунтовуючи своє рішення, використовував одночасно аргумент за аналогією, аргумент згоди, аргумент загальних принципів. Федеральний конституційний суд Німеччини у своєму рішенні у справі про Маастрихтський договір вдався до натуралістичних та системних аргументів.

Зроблено висновок, що конституційна ідентичність - це система інтерпретаційних аргументів, що використовуються конституційними судами для обгрунтування рішень, що перевіряють відповідність національній специфіці конституційних норм. Звичайно, це стосується категорій так званих «складних справ», для аргументації яких потрібна система вагомих аргументів.

Ключові слова: конституиійне провадження; конституційна аргументація; національна ідентичність; інтерпретаційний аргумент; конституціоналізм. 